\title{
Use of complementary and alternative medicine and adherence to antiepileptic drug therapy among epilepsy patients: a systematic review
}

This article was published in the following Dove Press journal: Patient Preference and Adherence

Muhammad Junaid Farrukh' Mohd Makmor-Bakry' Ernieda Hatah'

Hui Jan $\operatorname{Tan}^{2}$

'Faculty of Pharmacy, Universiti Kebangsaan Malaysia, Kuala Lumpur, Malaysia; ${ }^{2}$ Faculty of Medicine, Pusat Perubatan Universiti Kebangsaan Malaysia (PPUKM), Kuala Lumpur, Malaysia

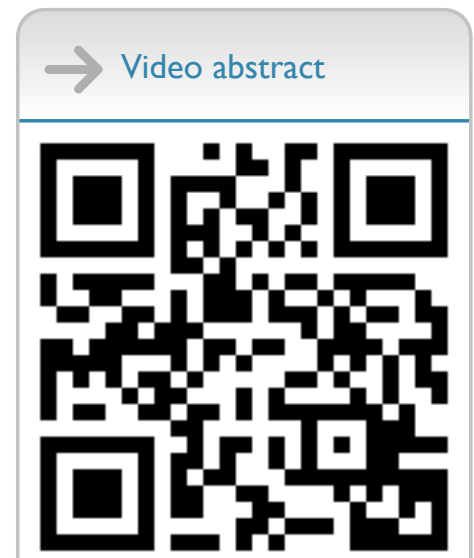

Point your SmartPhone at the code above. If you have a $Q R$ code reader the video abstract will appear. Or use: http://youtu.be/qI b0xRKfHdA

Correspondence: Mohd Makmor-Bakry Faculty of Pharmacy, Universiti Kebangsaan Malaysia, Jalan Raja Muda Abdul Aziz, 50300 Kuala Lumpur, Malaysia

Tel +60 392897244

Fax +60 32698327

Email mohdclinpharm@ukm.edu.my
Purpose: To identify the use pattern of complementary and alternative medicine (CAM) and its impact on antiepileptic drug (AED) adherence among patients with epilepsy.

Method: Potential studies were identified through a systematic search of Scopus, Science Direct, Google Scholar, and PubMed. The keywords used to identify relevant articles were "adherence," "AED," "epilepsy," "non-adherence," and "complementary and alternative medicine." An article was included in the review if the study met the following criteria: 1) conducted in epilepsy patients, 2) conducted in patients aged 18 years and above, 3) conducted in patients prescribed AEDs, and 4) patients' adherence to AEDs.

Results: A total of 3,330 studies were identified and 30 were included in the final analysis. The review found that the AED non-adherence rate reported in the studies was between 25\% and $66 \%$. The percentage of CAM use was found to be between $7.5 \%$ and $73.3 \%$. The most common reason for inadequate AED therapy and higher dependence on CAM was the patients' belief that epilepsy had a spiritual or psychological cause, rather than primarily being a disease of the brain. Other factors for AED non-adherence were forgetfulness, specific beliefs about medications, depression, uncontrolled recent seizures, and frequent medication dosage.

Conclusion: The review found a high prevalence of CAM use and non-adherence to AEDs among epilepsy patients. However, a limited number of studies have investigated the association between CAM usage and AED adherence. Future studies may wish to explore the influence of CAM use on AED medication adherence.

Keywords: medication adherence, AED, epilepsy, complementary and alternative medicine, non-compliance, CAM, seizure

\section{Introduction}

Epilepsy is a chronic, non-communicable disorder of the brain that could affect people of any age. Approximately 50 million people worldwide have epilepsy, making it one of the most common neurological diseases globally. ${ }^{1}$ Most seizures can be controlled with antiepileptic drugs (AEDs). Surgery to remove the epileptogenic lesion may also stop seizure activity. A ketogenic (high-fat, low-carbohydrate) diet may be used to treat epilepsy (recurrent seizures) in children, particularly if seizure medicines are not effective. ${ }^{2}$

CAM is sought by PWE as an alternative treatment option although its effectiveness has not been clearly established using scientific methods. CAM can be defined as "a broad domain of healing resources that encompasses all health systems, modalities, and practices, and their accompanying theories and beliefs, other than those intrinsic to the politically dominant health systems of a particular society or culture in a given historical period". ${ }^{3}$ CAM is reported to be used worldwide. ${ }^{4-6}$ In various 
Asian and African countries, CAM is the primary method of health care. ${ }^{7}$ Over the last decade, the interest in CAM has increased rapidly. ${ }^{8}$

Based on the National Center for Complementary and Alternative Medicine (NCCAM, 2005), CAMs are broadly divided into five types: biological, spiritual/mind-body, alternative, physical (body-based), and energy therapies. ${ }^{9}$ Biological methods, also known as natural products, include herbs, vitamins, dietary supplements, antioxidants, and minerals while mind and body practices include acupuncture, aromatherapy, cupping, massage, prayer for health (use of holy water, amulets, or talismans) and Zumba. Alternative medicine includes traditional medicines that vary from region to region, eg, traditional Chinese, Malay, Indian (Ayurvedic/ Siddha/Unani) medicines and homeopathy. ${ }^{9,10}$

The use of CAMs may vary due to differences in cultural norms and healthcare settings. A study performed in Malaysia demonstrated that $71.2 \%$ of respondents admitted to CAM use and the use of herbal products was the most popular CAM. The main reason for CAM use was recommendations from family and friends. ${ }^{11}$

Medication adherence or the older term, drug compliance, is defined as the extent to which patients follow the instructions they are given for prescribed treatments, and their persistence in completing the duration of time from initiation to discontinuation of therapy. ${ }^{12}$ Usually, measurements of medication adherence are classified by the WHO as subjective and objective measurements. ${ }^{13}$ Subjective measurements include those requiring the patient's evaluation of their medication-taking behavior. Self-reported questionnaires, eg, MMAS, and healthcare professional assessments are the most common tools used to assess medication adherence. ${ }^{14}$ Objective measures include pill counts, secondary database analysis such as the MPR, electronic monitoring, and biochemical measures. ${ }^{15}$ According to the WHO, the prevalence of AED adherence in developing countries ranges between $20 \%$ and $80 \%{ }^{16}$ In Malaysia, the prevalence of poor adherence to AEDs was documented in $64.1 \%$ of PWE, which is higher than the percentages reported in studies conducted in western populations. ${ }^{17}$

The four primary factors related to medication nonadherence are patient-related factors (eg, socioeconomic characteristics, and perceptions and beliefs), illness-related factors (eg, severity of illness and frequency of symptoms), medication-related factors (eg, number of daily doses, efficacy, and side effects), and physician-related factors (eg, patient-physician relationship). ${ }^{18-21}$ In a study performed in Malaysia, a busy lifestyle, forgetfulness, younger age, adverse effects of drugs, and limited contact time with a physician were identified as factors affecting adherence. ${ }^{17}$

Medication non-adherence is a serious issue in PWE and the belief that epilepsy has a spiritual or psychological cause may contribute to inadequate AED therapy and higher dependence on CAM, which can result in AED nonadherence. There is inadequate data on the impact of CAM on adherence among PWE. The purpose of this study was to determine the use pattern and impact of CAM on AED adherence among PWE.

\section{Methods}

Studies were identified through a comprehensive literature search of Scopus, Ovid, Medline, Science Direct, Google Scholar, and PubMed from the inception of these sources until May 2018. The keywords used for searching for relevant articles were "adherence," "compliance," "AED," "epilepsy," "non-adherence," "CAM," and "complementary and alternative medicine." Boolean operators such as 'AND' and 'OR' were used to increase the sensitivity and specificity of the search when needed. The articles identified were then screened based on the inclusion and exclusion criteria presented in Table 1. Initial titles/abstracts were screened by MJF. The exclusion process, using the title/abstract, was also performed by MJF if the reason for exclusion was clear. If there was uncertainty, the article was not excluded and was reviewed by MMB. Any disagreements on whether a study should be included/excluded were resolved through consensus. Data were extracted from a full-text report using

Table I Criteria for inclusion and exclusion of studies in the review

\begin{tabular}{|l|l|}
\hline Population & Epilepsy patients aged I8 and above \\
\hline $\begin{array}{l}\text { Phenomenon } \\
\text { of interest }\end{array}$ & $\begin{array}{l}\text { The phenomenon of interest included } \\
\text { - Use of CAM in developed and developing countries } \\
\text { - Types and reasons of CAM usage } \\
\text { - Adherence to AED }\end{array}$ \\
\hline $\begin{array}{l}\text { Primary } \\
\text { outcome } \\
\text { measure }\end{array}$ & $\begin{array}{l}\text { The outcome measures of interest included but were } \\
\text { not restricted to the following: } \\
\text { - Prevalence and types of CAM usage } \\
\text { - Prevalence of adherence and method of assessment } \\
\text { - Factors associated to medication non-adherence } \\
\text { - Impact of CAM on adherence and AED therapy }\end{array}$ \\
\hline $\begin{array}{l}\text { Types of } \\
\text { studies }\end{array}$ & $\begin{array}{l}\text { Quantitative cross-sectional surveys and qualitative } \\
\text { studies. Studies were included if they reported one or } \\
\text { more of the outcomes detailed above }\end{array}$ \\
\hline
\end{tabular}

Abbreviations: CAM, complementary and alternative medicine; AED, antiepileptic drug. 
a data extraction form, which included study characteristics, participant characteristics, rate of medication adherence, and adherence assessment methods. The primary outcomes of the current study were the rate of patients' adherence to AEDs, CAM use, and impact of CAM on AED adherence. The quality of the studies was assessed for potential bias by using the evaluation tool for quantitative research studies. ${ }^{22}$

\section{Results}

A total of 3,330 titles were retrieved and of this 93 were removed due to duplication. The remaining articles were screened for inclusion and exclusion criteria. Thirty studies were included in the final review. Figure 1 shows the flow of study identification.

Of the 30 studies, 16 focused on CAM usage among PWE, 13 reported medication adherence, and only one investigated CAM usage and patients' adherence to AEDs. The types of study design and country settings have been summarized in Tables 2-5.

\section{Prevalence and types of CAM usage}

In the 16 papers identified, the prevalence of CAM use was between $7.5 \%$ and $73.3 \%$. The use of CAM in developed countries was higher than that in the developing countries. However, the types of CAM used did not differ much, with some variation due to differences in cultural and traditional norms. The most prevalent type of CAMs reported in these studies were herbal $(n=6)$, prayer/spirituality $(n=5)$, and yoga/exercise $(n=5)$.

The belief that epilepsy has a spiritual or psychological cause, rather than being a primary ailment of the brain contributes to inadequate AED therapy and higher dependence on CAM, which results in inadequate AED treatment. $^{23}$

In developed countries, CAM treatments are frequently used for overall wellness or for chronic conditions, for instance, epilepsy or pain, that respond inadequately to standard treatments. ${ }^{24}$ In Western Europe and North America, regardless of availability and accessibility to advanced technology and evidence-based allopathic medicine, CAM is expanding in terms of its economic importance as a treatment choice for many health care needs. ${ }^{25}$ In most of the studies performed in the USA, yoga, botanicals (herbs), prayer/spirituality, vitamins, and stress reduction were the most frequently used methods in PWE. ${ }^{8,26,27}$ Majority of the patients did not disclose the use of CAM to their doctors. ${ }^{8,28}$

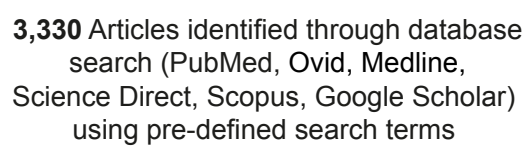

3,330 Articles identified through database search (PubMed, Ovid, Medline, Science Direct, Scopus, Google Scholar) using pre-defined search terms

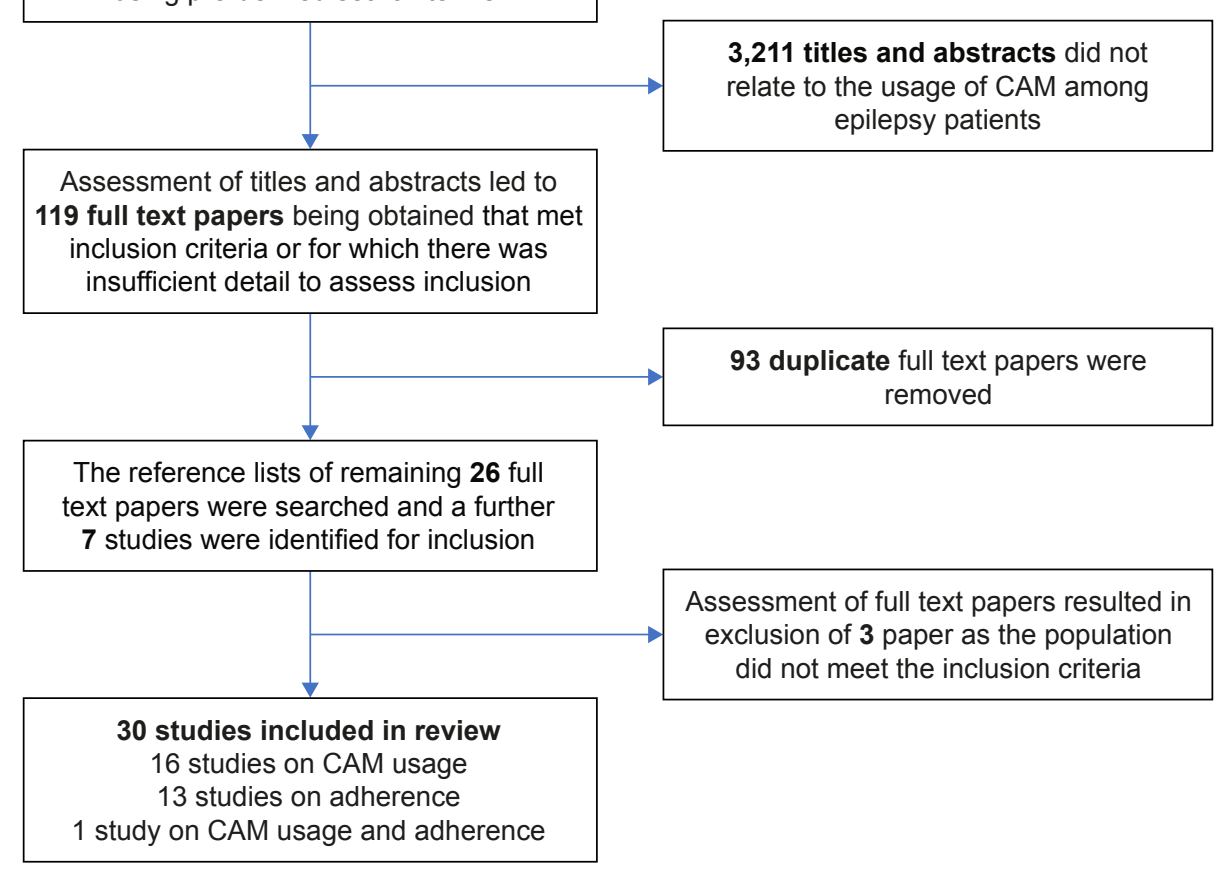

Figure I Flow diagram of searches and inclusion assessment of studies. Abbreviation: CAM, complementary and alternative medicine. 
Table 2 Prevalence and types of CAM use

\begin{tabular}{|c|c|c|c|c|c|c|c|c|c|}
\hline No & $\begin{array}{l}\text { Authors/type of } \\
\text { study }\end{array}$ & $\begin{array}{l}\text { Type of } \\
\text { population }\end{array}$ & Country & Year & $\begin{array}{l}\% \text { of } \\
\text { CAM } \\
\text { usage }\end{array}$ & Types of CAM used & $\begin{array}{l}\text { Mind } \\
\text { and body } \\
\text { practice }\end{array}$ & $\begin{array}{l}\text { Natural } \\
\text { products }\end{array}$ & $\begin{array}{l}\text { Alternative/ } \\
\text { traditional } \\
\text { medicine } \\
\end{array}$ \\
\hline I. & Szabo ${ }^{71}$ survey & $\begin{array}{l}\text { Epilepsy } \\
\mathrm{N}=34 \mathrm{I}\end{array}$ & USA & 2003 & $50 \%$ & $\begin{array}{l}\text { The most helpful were stress } \\
\text { reduction, yoga, and botanicals } \\
\text { (herbs) }\end{array}$ & $\sqrt{ }$ & $\sqrt{ }$ & - \\
\hline 2. & $\begin{array}{l}\text { Al Asmi et al }{ }^{34} \text { cross- } \\
\text { sectional }\end{array}$ & $\begin{array}{l}\text { Epilepsy } \\
\mathrm{N}=101\end{array}$ & Oman & 2013 & $73.3 \%$ & $\begin{array}{l}\text { Wearing (amulet) } 73 \% \\
\text { Herbal } 47 \%\end{array}$ & $\sqrt{ }$ & $\sqrt{ }$ & - \\
\hline 3. & $\begin{array}{l}\text { Mcconnell et } \mathrm{al}^{27} \\
\text { survey }\end{array}$ & $\begin{array}{l}\text { Epilepsy } \\
\mathrm{N}=120\end{array}$ & USA & 2014 & $70 \%$ & $\begin{array}{l}\text { Prayer/spirituality (31\%), } \\
\text { meditation (19\%), vitamins } \\
(19 \%) \text {, and stress management } \\
(16 \%)\end{array}$ & $\sqrt{ }$ & $\sqrt{ }$ & - \\
\hline 4. & Liow et $a^{26}$ survey & $\begin{array}{l}\text { Epilepsy } \\
\mathrm{N}=228\end{array}$ & USA & 2007 & $25 \%$ & $\begin{array}{l}\text { Prayer/spirituality }(46 \%), \\
\text { vitamins }(25 \%) \text {, chiropractic } \\
\text { care }(24 \%), \text { and stress } \\
\text { management }(16 \%)\end{array}$ & $\sqrt{ }$ & $\sqrt{ }$ & - \\
\hline 5. & $\begin{array}{l}\text { Easterford et } \mathrm{a}^{28} \\
\text { survey }\end{array}$ & $\begin{array}{l}\text { Epilepsy } \\
\mathrm{N}=400\end{array}$ & UK & 2005 & $34.6 \%$ & - & - & - & - \\
\hline 6. & $\begin{array}{l}\text { Kim et al }{ }^{40} \text { structured } \\
\text { interviews }\end{array}$ & $\begin{array}{l}\text { Epilepsy } \\
\mathrm{N}=246\end{array}$ & Korea & 2006 & $31.3 \%$ & - & - & - & - \\
\hline 7. & $\begin{array}{l}\text { Tandon et } \mathrm{al}^{35} \text { patient } \\
\text { interview }\end{array}$ & $\begin{array}{l}\text { Epilepsy } \\
\mathrm{N}=1,000\end{array}$ & India & 2002 & $32 \%$ & $\begin{array}{l}\text { Ayurvedic (43\%) homeopathy } \\
(12.5 \%)\end{array}$ & - & $\sqrt{ }$ & $\sqrt{ }$ \\
\hline 8. & $\begin{array}{l}\text { Kuan et al }{ }^{39} \\
\text { interviews }\end{array}$ & $\begin{array}{l}\text { Epilepsy } \\
\mathrm{N}=403\end{array}$ & Taiwan & 2011 & $49.1 \%$ & $\begin{array}{l}\text { Traditional Chinese medicine } \\
(51.5 \%) \text { and temple worship } \\
(48.0 \%)\end{array}$ & $\sqrt{ }$ & - & $\sqrt{ }$ \\
\hline 9. & $\begin{array}{l}\text { Sirven et } a^{8} \text { survey } \\
\text { (email) }\end{array}$ & $\begin{array}{l}\text { Epilepsy } \\
\mathrm{N}=425\end{array}$ & USA & 2003 & $44 \%$ & $\begin{array}{l}\text { Stress reduction (68\%), yoga } \\
(57 \%) \text {, and botanicals }(55 \%)\end{array}$ & $\sqrt{ }$ & $\sqrt{ }$ & - \\
\hline 10. & $\begin{array}{l}\text { Harms et } \mathrm{al}^{30} \\
\text { pharmaco- } \\
\text { epidemiology study }\end{array}$ & $\begin{array}{l}\text { Epilepsy } \\
\mathrm{N}=? ?\end{array}$ & USA & 2006 & $23 \%$ & $\begin{array}{l}\text { Ginkgo accounted for } 61.9 \% \\
\text { among epilepsy patients }\end{array}$ & - & $\sqrt{ }$ & - \\
\hline II. & Peebles et $\mathrm{a}^{29}$ survey & $\begin{array}{l}\text { Epilepsy } \\
\mathrm{N}=150\end{array}$ & $\begin{array}{l}\text { USA } \\
\text { (Columbus) }\end{array}$ & 2000 & $24 \%$ & $\begin{array}{l}\text { Massage }(50 \%) \text { and herbs/ } \\
\text { supplements }(41 \%) \text { were used } \\
\text { the most }\end{array}$ & $\sqrt{ }$ & $\sqrt{ }$ & - \\
\hline 12. & $\begin{array}{l}\text { Asadi-Pooya } \\
\text { and Emami }{ }^{33} \\
\text { cross-sectional }\end{array}$ & $\begin{array}{l}\text { Epilepsy } \\
\mathrm{N}=158\end{array}$ & Iran & 2014 & $14.5 \%$ & $\begin{array}{l}\text { Herbal drugs, traditional } \\
\text { medicine and exercise }\end{array}$ & $\sqrt{ }$ & $\sqrt{ }$ & $\sqrt{ }$ \\
\hline 13. & $\begin{array}{l}\text { Bhalerao et } \mathrm{al}^{36} \\
\text { survey }\end{array}$ & $\begin{array}{l}\text { Epilepsy } \\
\mathrm{n}=150\end{array}$ & India & 2013 & $7.7 \%$ & $\begin{array}{l}\text { Ayurveda } 46 \% \text {, homeopathy } \\
22 \% \text {, yoga } 22 \%\end{array}$ & $\sqrt{ }$ & - & $\sqrt{ }$ \\
\hline 14. & $\begin{array}{l}\text { Naveen et al }{ }^{37} \\
\text { cross-sectional }\end{array}$ & $\begin{array}{l}\text { Epilepsy } \\
\mathrm{N}=300\end{array}$ & India & 2013 & $28.7 \%$ & $\begin{array}{l}\text { Ayurveda }(26.7 \%) \text {, yoga } \\
(25.6 \%) \text { homeopathy }(16.3 \%) \text {, } \\
\text { folk medicine }(29.1 \%)\end{array}$ & $\sqrt{ }$ & $\sqrt{ }$ & $\sqrt{ }$ \\
\hline 15. & $\begin{array}{l}\text { Razali and Yassin }{ }^{32} \\
\text { survey }\end{array}$ & $\begin{array}{l}\text { Epilepsy } \\
\mathrm{N}=60\end{array}$ & Malaysia & 2008 & $26.7 \%$ & $\begin{array}{l}\text { Traditional healers (bomoh) } \\
\text { and homeopathic practitioners }\end{array}$ & - & $\sqrt{ }$ & $\sqrt{ }$ \\
\hline 16. & $\mathrm{Pal}$ et $\mathrm{al}^{|3|}$ interview & $\begin{array}{l}\text { Epilepsy } \\
\mathrm{N}=400\end{array}$ & India & 2008 & $7.5 \%$ & Faith healers, amulets, massage & $\sqrt{ }$ & $\sqrt{ }$ & - \\
\hline
\end{tabular}

Note: - indicates that this category of CAM was not reported in the study.

Abbreviation: CAM, complementary and alternative medicine.

In one survey among PWE in the USA, the most commonly used herbs were ginseng, St John's wort, ginkgo (Ginkgo biloba), and garlic. ${ }^{29}$ These results were consistent with those of a study that showed that garlic and ginkgo were most frequently used by PWE. ${ }^{30}$

Use of amulets, prayer for health, and visits to faith healers were common among Islamic countries. ${ }^{31-34}$ Some types of CAM are more specific to a region and may vary between countries. The use of Ayurvedic medicine has been reported in several studies in India. ${ }^{35-37}$ In Taiwan, traditional Chinese medicine is quite prevalent since it was established in China about 3,000 years ago. ${ }^{38}$ The Taiwanese have been greatly influenced by Chinese culture. Many Taiwanese believe that worship can cure an illness. ${ }^{39}$ The prevalence and types of CAM used in developed and developing countries are summarized in Table 2. 
Table 3 Prevalence of adherence and methods of assessment

\begin{tabular}{|c|c|c|c|c|c|c|}
\hline No & Authors/type of study & $\begin{array}{l}\text { Type of } \\
\text { population }\end{array}$ & Country & Year & $\begin{array}{l}\text { Prevalence of } \\
\text { non-adherence }\end{array}$ & Method of assessment \\
\hline I. & $\begin{array}{l}\text { Chesaniuk et al }{ }^{58} \\
\text { internet based survey }\end{array}$ & $\begin{array}{l}\text { Epilepsy } \\
\mathrm{N}=140\end{array}$ & USA & 2014 & $25 \%$ & $\begin{array}{l}\text { Knobel brief adherence } \\
\text { questionnaire }\end{array}$ \\
\hline 2. & $\begin{array}{l}\text { Sweileh et al }{ }^{57} \\
\text { cross-sectional }\end{array}$ & $\begin{array}{l}\text { Epilepsy } \\
\mathrm{N}=75\end{array}$ & Palestine & 2011 & $64 \%$ & MMAS \\
\hline 3. & $\begin{array}{l}\text { Hovinga et al }{ }^{48} \\
\text { cross-sectional }\end{array}$ & $\begin{array}{l}\text { Epilepsy } \\
\mathrm{N}=408\end{array}$ & USA & 2008 & $29 \%$ & - \\
\hline 4. & $\begin{array}{l}\text { Paschal et al }{ }^{54} \\
\text { cross-sectional }\end{array}$ & $\begin{array}{l}\text { Epilepsy } \\
\mathrm{N}=180\end{array}$ & USA & 2014 & $30 \%$ & Self-reported questionnaire \\
\hline 5. & $\begin{array}{l}\text { Chapman et al }{ }^{42} \\
\text { cross-sectional }\end{array}$ & $\begin{array}{l}\text { Epilepsy } \\
\mathrm{N}=438\end{array}$ & UK & 2014 & $37 \%$ & $\begin{array}{l}\text { Epilepsy Self-Management } \\
\text { Scale and MPR }\end{array}$ \\
\hline 6. & $\begin{array}{l}\text { Ferrari et al }{ }^{44} \\
\text { cross-sectional }\end{array}$ & $\begin{array}{l}\text { Epilepsy } \\
\mathrm{N}=385\end{array}$ & Brazil & 2013 & $66 \%$ & Morisky green scale \\
\hline 7. & $\begin{array}{l}\text { Jones et al }{ }^{46} \\
\text { cross-sectional }\end{array}$ & $\begin{array}{l}\text { Epilepsy } \\
\mathrm{N}=54\end{array}$ & UK & 2006 & $59 \%$ & MMAS-4 \\
\hline 8. & Guo et $\mathrm{al}^{45}$ survey & $\begin{array}{l}\text { Epilepsy } \\
\mathrm{N}=184\end{array}$ & China & 2015 & $40 \%$ & MMAS-8 \\
\hline 9. & $\begin{array}{l}\text { Shallcross et al }{ }^{47} \\
\text { cross-sectional }\end{array}$ & $\begin{array}{l}\text { Epilepsy } \\
\mathrm{N}=55\end{array}$ & USA & 2015 & $36 \%$ & MMAS-8 \\
\hline 10. & $\begin{array}{l}\text { Smithson et } \mathrm{al}^{49} \\
\text { survey }\end{array}$ & $\begin{array}{l}\text { Epilepsy } \\
\mathrm{N}=438\end{array}$ & UK & 2013 & $30 \%$ & $\begin{array}{l}\text { Self-reported questionnaire } \\
\text { and MPR }\end{array}$ \\
\hline II. & $\begin{array}{l}\text { Molugulu et al }{ }^{55} \\
\text { cross-sectional }\end{array}$ & $\begin{array}{l}\text { Epilepsy } \\
\mathrm{N}=272\end{array}$ & Malaysia & 2016 & $49 \%$ & $\begin{array}{l}\text { Patient administered } \\
\text { questionnaire }\end{array}$ \\
\hline 12. & $\begin{array}{l}\text { Nakhutina et al }{ }^{51} \\
\text { cross-sectional }\end{array}$ & $\begin{array}{l}\text { Epilepsy } \\
\mathrm{N}=72\end{array}$ & USA & 2011 & $63 \%$ & MMAS-4 \\
\hline 13. & Zeber et $\mathrm{al}^{56}$ survey & $\begin{array}{l}\text { Epilepsy } \\
\mathrm{N}=6,373\end{array}$ & USA & 2010 & $48 \%$ & MPR \\
\hline
\end{tabular}

Note: - indicates method of adherence assessment was not revealed in this study.

Abbreviations: MMAS, Morisky Medication Adherence Scale; MPR, medication possession ratio.

Factors and reasons associated with CAM use

Among 16 papers identified, only eight papers reported the reasons for CAM use. The most commonly reported factors included fear of AED-related side effects $(n=4)^{31,33-36,40}$ and poor seizure control $(n=3){ }^{28,39,40}$ Two studies reported the influence of family members as the reason for CAM usage. 35,40

It is worthwhile to note that patients attributed their epilepsy to factors outside the realm of a biomedical model, including spirit possession (Jinn), evil eyes, contemptuous envy, or sorcery. ${ }^{32,41}$ Therefore, it seems consistent that most people adhere to a holistic perspective or to scriptural teaching (Holy Qur'an) as a health aid to their epilepsy. In addition to being a health aid, it is possible that CAM is used to reduce social stigma. For example, in Oman, the presence of hyper salivation and belief in spirits as the causes of epilepsy were strong predictors of CAM use. ${ }^{34}$

\section{Prevalence of medication non-adherence among PWE}

The prevalence of non-adherence in 13 studies ranged between 25\% and 66\% as shown in Figure 2. The overall adherence level in western countries was higher than that in Asian counties. This reflects that people living in developing countries prefer traditional medicines to modern allopathic medicines, which may lead to non-adherence.

Many adherence calculation methods were used across the included studies. ${ }^{42-45}$ The MMAS was used in four surveys. ${ }^{44-47}$ Two studies used the MMAS-4 tool and two studies used the MMAS-8. ${ }^{45,47}$ Hovinga et al used a 1-month recall period method to measure adherence. ${ }^{48}$ Two studies used a mixed-method approach using two items from the Epilepsy Self-Management Scale along with the MPR tool. MPR scores were determined using the participants' medication records in both these studies. ${ }^{42,49}$ MPR was determined by dividing the number of days on which medication was available by the number of days between the earliest prescription claims in the observation period through the end of the observation period with a threshold of $<0.80$ defining non-adherence..$^{50}$ The prevalence of non-adherence and methods of assessment across all the 13 studies have been listed in Table 3.

\section{Factors associated with non-adherence}

Factors associated with medication non-adherence across the 13 studies are outlined in Table 4. In two studies, perceptions of barriers, lack of motivation to take medication, fear 
Table 4 Factors associated with medication non-adherence

\begin{tabular}{|c|c|c|c|c|c|c|}
\hline No & $\begin{array}{l}\text { Authors/type of } \\
\text { study }\end{array}$ & Country & $\begin{array}{l}\text { Patient-related factors } \\
\text { (socio-economic, } \\
\text { perceptions and beliefs) }\end{array}$ & $\begin{array}{l}\text { Illness-related factors } \\
\text { (severity of illness } \\
\text { and frequency of } \\
\text { symptoms) }\end{array}$ & $\begin{array}{l}\text { Medication-related } \\
\text { factors } \\
\text { (number of daily doses, } \\
\text { efficacy, and side } \\
\text { effects), cost }\end{array}$ & $\begin{array}{l}\text { Physician-related } \\
\text { factors } \\
\text { (patient-physician } \\
\text { relationship) }\end{array}$ \\
\hline I. & $\begin{array}{l}\text { Chesaniuk et } \mathrm{al}^{58} \\
\text { internet based survey }\end{array}$ & USA & $\begin{array}{l}\sqrt{ } \\
\text { Higher perceived epilepsy- } \\
\text { related stigma }\end{array}$ & - & - & - \\
\hline 2. & $\begin{array}{l}\text { Jones et al }{ }^{46} \\
\text { cross-sectional }\end{array}$ & UK & - & $\begin{array}{l}\sqrt{ } \\
\text { Poor seizure control }\end{array}$ & - & - \\
\hline 3. & $\begin{array}{l}\text { Sweileh et a }{ }^{57} \\
\text { cross-sectional }\end{array}$ & Palestine & $\begin{array}{l}\sqrt{ } \\
\text { Stress } 41 \%\end{array}$ & - & $\begin{array}{l}\sqrt{ } \\
\text { Missed dose } 13 \%\end{array}$ & - \\
\hline 4. & $\begin{array}{l}\text { Hovinga et al }{ }^{48} \\
\text { cross-sectional }\end{array}$ & USA & $\begin{array}{l}\sqrt{ } \\
\text { Forgetfulness } 72 \%\end{array}$ & $\begin{array}{l}\sqrt{ } \\
\text { Poor seizure control }\end{array}$ & $\begin{array}{l}\sqrt{ } \\
\text { Cost } 13 \% \\
\text { Side effects } 9 \%\end{array}$ & $\sqrt{ }$ \\
\hline 5. & $\begin{array}{l}\text { Paschal et al }{ }^{54} \\
\text { cross-sectional }\end{array}$ & USA & $\begin{array}{l}\sqrt{ } \\
\text { Forgetfulness } 68 \%\end{array}$ & - & $\sqrt{ }$ & - \\
\hline 6. & $\begin{array}{l}\text { Chapman et al }{ }^{42} \\
\text { cross-sectional }\end{array}$ & UK & $\begin{array}{l}\sqrt{ } \\
\text { Negative perception of } \\
\text { AED }(36.4 \%)\end{array}$ & t & t & - \\
\hline 7. & $\begin{array}{l}\text { Ferrari et al }{ }^{44} \\
\text { cross-sectional }\end{array}$ & Brazil & $\begin{array}{l}\sqrt{ } \\
\text { Forgetfulness }(47.5 \%) \\
\text { Lack of time }(39.2 \%)\end{array}$ & $\begin{array}{l}\sqrt{ } \text { Worsening symptoms } \\
(9.0 \%)\end{array}$ & $\begin{array}{l}\sqrt{ } \\
\text { Poly pharmacy } 66 \%,\end{array}$ & - \\
\hline 8. & $\begin{array}{l}\text { Guo et a }{ }^{45} \\
\text { cross-sectional }\end{array}$ & China & $\begin{array}{l}\sqrt{ } \\
\text { Depression, anxiety }\end{array}$ & - & - & - \\
\hline 9. & $\begin{array}{l}\text { Shallcross et al }{ }^{47} \\
\text { cross-sectional }\end{array}$ & USA & $\begin{array}{l}\sqrt{ } \\
\text { Depression }(21 \%)\end{array}$ & - & - & - \\
\hline 10. & $\begin{array}{l}\text { Molugulu et al }{ }^{55} \\
\text { cross-sectional }\end{array}$ & Malaysia & $\begin{array}{l}\sqrt{ } \\
\text { Patient understanding }\end{array}$ & $\begin{array}{l}\sqrt{ } \\
\text { Seizure frequency }\end{array}$ & $\sqrt{ }$ & - \\
\hline 11. & $\begin{array}{l}\text { Nakhutina et a }{ }^{51} \\
\text { cross-sectional }\end{array}$ & USA & $\begin{array}{l}\sqrt{ } \\
\text { Forgetfulness } \\
\text { beliefs about medicines }\end{array}$ & - & - & - \\
\hline 12. & $\begin{array}{l}\text { Zeber et al }{ }^{56} \\
\text { survey }\end{array}$ & USA & - & - & $\begin{array}{l}\sqrt{ } \\
\text { Side effects }\end{array}$ & - \\
\hline 13. & $\begin{array}{l}\text { Durón et } \mathrm{al}^{23} \\
\text { observational study }\end{array}$ & USA & $\begin{array}{l}\sqrt{ } \\
\text { Forgetfulness } 13.2 \%\end{array}$ & - & $\begin{array}{l}\sqrt{ } \\
\text { AED unavailability } 48 \%\end{array}$ & - \\
\hline
\end{tabular}

Note: - indicates that this category of factor was not reported in this study.

Abbreviation: AED, antiepileptic drug.

of adverse effects, and knowledge gap were reported to be the causes for medication non-adherence among PWE..$^{51,52}$ Others factors such as difficulty in opening container lids or shortage of medication in the market were also reported to cause AED non-adherence. ${ }^{51,53}$

\section{Patient-related factors}

In four of the included studies, females were reported to be more likely to comply with AEDs. ${ }^{44,45,48,49}$ Depression and anxiety were associated with poor adherence in two studies. ${ }^{45,47}$ In one study, a significant difference in depression scores was reported between the low and the moderate-tohigh adherence groups $(P<0.001){ }^{45}$ Four studies reported forgetfulness as the reason for AED non-adherence. ${ }^{44,48,51,54}$

\section{Illness-related factors}

Four studies investigated the associations between adherence and seizure control..$^{44,46,48,55}$ Ferrari et al reported no significant

Table 5 CAM usage and adherence among epilepsy patients

\begin{tabular}{l|l|l|l|l|l|l|l|l|l|l}
\hline No & $\begin{array}{l}\text { Authors/type } \\
\text { of study }\end{array}$ & $\begin{array}{l}\text { Type of } \\
\text { population }\end{array}$ & Country & Year & $\begin{array}{l}\text { Prevalence } \\
\text { of adherence }\end{array}$ & $\begin{array}{l}\text { \% of } \\
\text { CAM } \\
\text { usage }\end{array}$ & $\begin{array}{l}\text { Types of } \\
\text { CAM used }\end{array}$ & $\begin{array}{l}\text { Mind } \\
\text { and body } \\
\text { practices }\end{array}$ & $\begin{array}{l}\text { Natural } \\
\text { products }\end{array}$ & $\begin{array}{l}\text { Alternative/ } \\
\text { traditional } \\
\text { medicine }\end{array}$ \\
\hline I. & $\begin{array}{l}\text { Durón et al } \\
\text { observational } \\
\text { study }\end{array}$ & $\begin{array}{l}\text { Epilepsy patient } \\
\mathrm{N}=274\end{array}$ & $\begin{array}{l}\text { Central } \\
\text { America }\end{array}$ & 2009 & $55.8 \%$ & $51.5 \%$ & $\begin{array}{l}\text { Prayer, herbs, } \\
\text { potions and } \\
\text { massage }\end{array}$ & $\sqrt{ }$ & $\sqrt{ }$ & $\sqrt{ }$ \\
\hline
\end{tabular}

Abbreviation: CAM, complementary and alternative medicine. 


\section{Prevalence of non adherence}

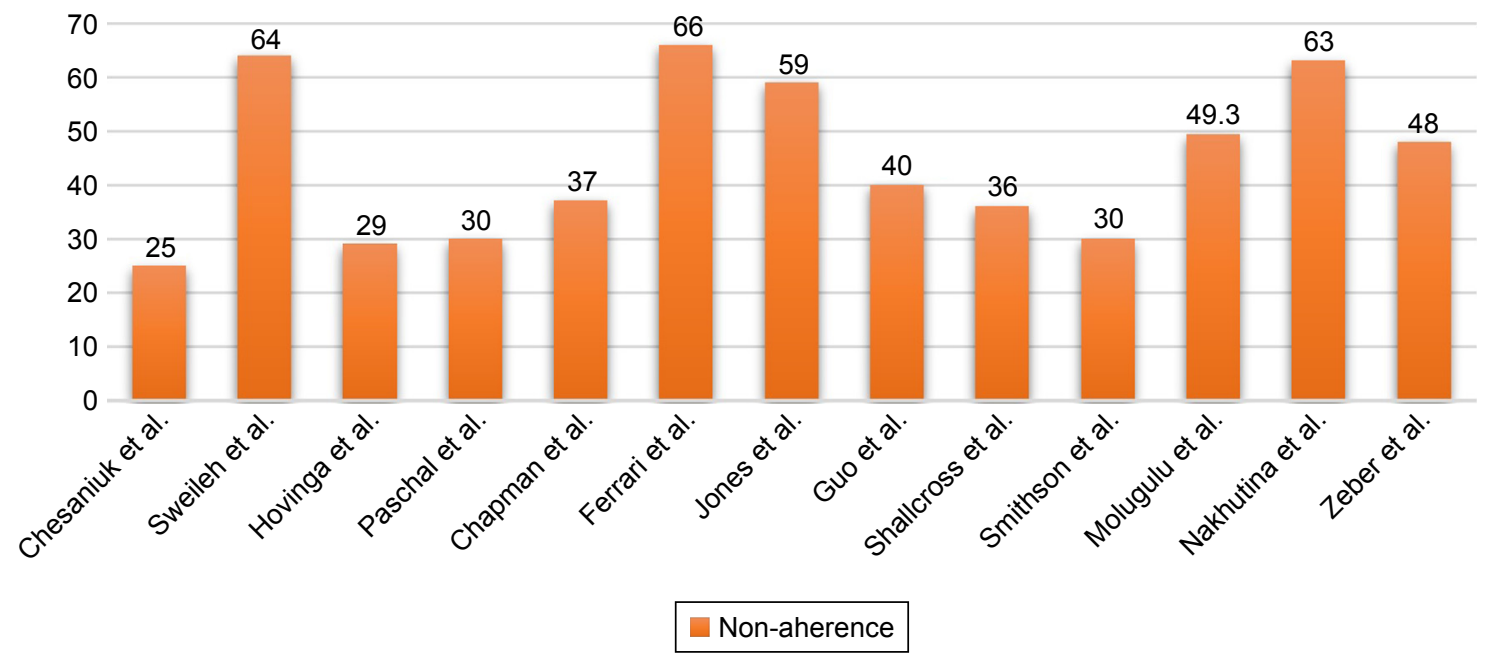

Figure 2 Outlines AED non-adherence rates for thirteen studies. Abbreviation: AED, antiepileptic drug.

association between seizure control and adherence to medication. ${ }^{44}$ Other three studies demonstrated a strong correlation between poor seizure control and non-adherence. ${ }^{46,48,55}$

\section{Medication-related factors}

The most significant medication-related factors associated with non-adherence included missed doses, poly pharmacy, high cost, and medication side effects. ${ }^{44,48,56,57}$ In the study by Ferrari et al, $45 \%$ of patients who received mono therapy showed high treatment adherence while the rest showed moderate-to-low adherence. ${ }^{44}$ Nevertheless, Guo et al reported that non-adherence to AED had no significant association with mono/poly therapy $(P>0.05) .{ }^{45}$ AED unavailability $(48 \%)$ was the major factor leading to non-adherence. ${ }^{23}$

\section{Physician-related factors}

One study investigated the impact of the patient-physician relationship and found that trust in doctors was more prevalent among adherent patients (34\%) compared to that in non-adherent patients (17\%). Furthermore, adherent participants reported being comfortable while disclosing missed medications to their doctor ( $27 \%$ vs $12 \%) .^{48}$ Other studies did not indicate the patient-physician relation and its impact on adherence.

\section{Impact of CAM on adherence and AED therapy}

There seemed to be a deficiency of clinical evidence about AED non-adherence and CAM use. However, Durón et al assessed adherence to AEDs and CAM use and found nonadherence to AED in 121 patients, with the unavailability of AEDs (48\%) being the most common reason for nonadherence and prayer, herbs, and potions being the common
CAMs used as shown in Table 5. Among 51.5\% of CAM users, $44.2 \%$ reported that they had stopped taking their AEDs. $^{23}$

\section{Quality of included studies}

Quality varied across the studies included. The response rate varied from $11 \%$ to $79.5 \%$. Nine studies did not report response rates. ${ }^{28,31,33,39,40,46,47,56,58}$ The manner in which participants were recruited and the sample size was determined were not clearly reported in seven studies. ${ }^{28,29,31,40,46,54}$ Types of CAM used were not explained in two studies. ${ }^{28,40}$ Patients' adherence to medication was mostly assessed using the MMAS (n=6). ${ }^{44-47,56,57}$ Three studies did not clearly explain how medication adherence was measured. ${ }^{48,54,55}$

\section{Discussion}

In the current study, we reviewed the use pattern and impact of CAM on AED adherence among PWE. We included 30 studies in this review and a particular concern was the low response rate in the included surveys. The variable methodological quality of many included studies is identified as a study limitation. Nine studies did not report the response rate. Further problems with surveys of CAM were related to the fact that no universally accepted definition of CAM exists. This means that different surveys monitor the use of different methods. Self-reported questionnaires typically provide overestimates of adherence for several reasons: first, they may rely on patients' own interpretation or memory of what advice was given and, if accepted, how closely it has been followed; and second, patients may tend to report higher levels of adherence in order to please health care providers or avoid embarrassment. ${ }^{59}$ CAM therapies for epilepsy in 
developing countries have evolved over the centuries, often in conjunction with the health care system, education level, and changing cultural beliefs. ${ }^{40}$ The use of CAM in developed countries was higher than that in developing countries, with some variation due to the difference in cultural and traditional norms.

The most prevalent types of CAM reported in the studies reviewed were the use of herbal products, prayer/spirituality, and yoga/exercise. Fear of AED-related side effects and poor seizure control were the most frequently reported reasons for using CAM. Although pharmacological treatments of epilepsy have been shown to be efficacious in mitigating various types of epilepsies, the side effects of these medications result in adverse effects on the patients' quality of life, often resulting in poor compliance. ${ }^{57}$ This is likely to contribute to a shift toward the use of CAM among PWE. ${ }^{44}$ Studies have shown that many PWE tend to concurrently use both CAM and antiepileptic medication. This may be due to attractive marketing strategies used by herbal and vitamin companies that make claims of the safety and benefits of CAM, which attract patients; however, there is limited scientific evidence of their efficacy and safety in epilepsy. ${ }^{60}$ Some studies have further shown that some PWE tend not to disclose their use of CAM to their health care providers working under the auspices of biomedical care. ${ }^{48}$

In several countries, it is believed that epilepsy is linked to supernatural or spiritual causes, which may lead to undertreatment and greater reliance on CAM use. ${ }^{26,40,61}$ In these countries, it is believed that diseases caused by supernatural things cannot be cured with allopathic medicine and CAM should be used to treat such patients. ${ }^{26,31,40}$ Cultural views complicate the issue of medication non-adherence. ${ }^{23,61,62}$ Patients prefer CAM assuming that spirit possession is the cause of epilepsy and they seldom consider AEDs as the primary therapy. ${ }^{23}$ In many surveys, a significant percentage of PWE used CAM. ${ }^{26,40,61}$ Surveys conducted in multicultural regions show that vitamins, prayer for health, and stress management are the most frequently used types of CAM. ${ }^{23,26,63}$ Patients who associated epilepsy with non-biological causes, such as spirits and exorcism, often visited faith healers before going to a doctor which led to under-treatment and greater reliance on CAM usage. ${ }^{34}$ These findings indicate the need for educating people and spreading awareness regarding epilepsy and the role of AEDs in the treatment of epilepsy. ${ }^{34}$ However, there is no direct evidence from the reviewed literature that belief in the spiritual nature of epilepsy affects AED adherence. Further studies are needed to check the association of spiritual belief and AED adherence.
The prevalence of AED non-adherence was reported in 13 of the studies and ranged between $25 \%$ and $66 \%$. However, the assessment methods used in these studies were mainly subjective (patient-reported questionnaires) and tended to overestimate patient adherence. Using a mixed-method approach (ie, using subjective and objective assessment tools), patient adherence can be more effectively estimated. Forgetfulness, specific beliefs about medications, depression, uncontrolled recent seizures, frequent medication dosage times and poly pharmacy were the most frequently reported factors associated with AED non-adherence. Similar findings were reported in a study where people using poly therapy were more likely to forget to take their medication. ${ }^{70}$

Pharmacists should conduct counseling and educational programs to help patients improve medication adherence and change their false perception about the etiology of epilepsy. A study showed that the level of knowledge could possibly influence the levels of adherence to medications, and pharmacists could play a more active role in ensuring proper information is disseminated based on the education level of the patients. ${ }^{64}$ These findings are consistent with those of a study in which the compliance rate was high among patients with good knowledge about their disease ${ }^{65}$ Furthermore, the use of various compliance aids such as pill boxes, medication reminders, and combination therapy (where possible) to reduce the number of pills can improve adherence. ${ }^{66}$ Since depression may reduce patients' adherence to medication, lower rates of depression may be associated with better medication adherence. ${ }^{67}$ Organizational religious activity had a significant positive association with adherence to medications and it can lower depression. ${ }^{68,69}$

Although many studies have reported the reasons for CAM usage among PWE, there seemed to be limited evidence on AED non-adherence due to CAM usage. ${ }^{23}$ Among the 30 studies included in this review, the association between AED adherence and CAM use was assessed in only one study. ${ }^{23}$ More studies should be performed to investigate the resultant effects of CAM use by PWE to gather detailed information on whether the treatment under consideration has a positive or negative impact on the patient's health condition and adherence to AED.

\section{Conclusion}

Medication non-adherence is associated with forgetfulness, shortage of medication, cultural beliefs, and the use of CAMs instead of AEDs. An intensive education program should be the priority for changing patients' beliefs. Awareness should be raised regarding the etiology of epilepsy and effectiveness 
of AEDs in treating epilepsy. Governments and pharmaceutical industries need to collaborate to access, obtain, store, and distribute AEDs effectively. Moreover, further studies are needed to investigate the effects of CAM in epilepsy and its impact on medication adherence, to provide insight into whether or not the treatments being used are beneficial since the studies comparing the impact of CAM on adherence and AED therapy are limited.

\section{Abbreviations}

AED, antiepileptic drug therapy; CAM, complementary and alternative medicine; MMAS, Morisky Medication Adherence Scale; MPR, medication possession ratio; PWE, patients with epilepsy.

\section{Author contributions}

All authors contributed to data analysis, drafting and revising the article, gave final approval of the version to be published, and agree to be accountable for all aspects of the work.

\section{Disclosure}

The authors report no conflicts of interest in this work.

\section{References}

1. WHO. Epilepsy Fact Sheet; 2016. Available from: http://www.who. int/mediacentre/factsheets/fs999/en/. Accessed March 20, 2018.

2. Marks WJ, Garcia PA. Management of seizures and epilepsy. Am Fam Physician. 1998;57(7):15891603-16001604.

3. Zollman C, Vickers A. ABC of complementary medicine: What is complementary medicine? BMJ. 1999;319(7211):693-696.

4. Shaikh SH, Malik F, James H, Abdul H. Trends in the use of complementary and alternative medicine in Pakistan: a population-based survey. J Altern Complement Med. 2009;15(5):545-550.

5. Fox P, Coughlan B, Butler M, Kelleher C. Complementary alternative medicine (CAM) use in Ireland: a secondary analysis of SLAN data. Complement Ther Med. 2010;18(2):95-103.

6. Aydin S, Bonkaya AO, Mazicioglu MM, Gemalmaz A, Ozturk A. What influences herbal medicine use?-prevalence and related factors. Turk $J$ Med Sci. 2008;38(5):455-463.

7. Jeong MJ, Lee HY, Lim JH, Yun YJ. Current utilization and influencing factors of complementary and alternative medicine among children with neuropsychiatric disease: a cross-sectional survey in Korea. BMC Complement Altern Med. 2016;16(1):91.

8. Sirven JI, Drazkowski JF, Zimmerman RS, et al. Complementary/ alternative medicine for epilepsy in Arizona. Neurology. 2003;61(4): 576-577.

9. Wieland LS, Manheimer E, Berman BM. Development and classification of an operational definition of complementary and alternative medicine for the Cochrane collaboration. Altern Ther Health Med. 2011; 17(2):50.

10. Rhodes PJ, Small N, Ismail H, Wright JP. The use of biomedicine, complementary and alternative medicine, and ethnomedicine for the treatment of epilepsy among people of South Asian origin in the UK. BMC Complement Altern Med. 2008;8(1):7.

11. Jasamai M, Islahudin F, Samsuddin NF. Attitudes towards complementary alternative medicine among Malaysian adults. J Appl Pharm Sci. 2017;7(06):190-193.
12. Shams ME, Barakat EA. Measuring the rate of therapeutic adherence among outpatients with T2DM in Egypt. Saudi Pharm J. 2010; 18(4):225-232.

13. WHO. Adherence to long-term therapies: evidence for action; 2003. Available from: http://www.who.int/chp/knowledge/publications/ adherence_report/en/. Accessed March 29, 2018.

14. Velligan DI, Wang M, Diamond P, et al. Relationships among subjective and objective measures of adherence to oral antipsychotic medications. Psychiatr Serv. 2007;58(9):1187-1192.

15. Vermeire E, Hearnshaw H, van Royen P, Denekens J. Patient adherence to treatment: three decades of research. A comprehensive review. J Clin Pharm Ther. 2001;26(5):331-342.

16. WHO. Adherence to Long-term Therapies: Evidence For Action. Geneva: World Health Organization; 2003. http://www.who.int/chp/knowledge/ publications/adherence_report/en/. Accessed September 14, 2018.

17. Tan X, Makmor Bakry M, Lau C, Tajarudin F, Raymond A. Factors affecting adherence to antiepileptic drugs therapy in Malaysia. Neurol Asia. 2015;20(3):235-241.

18. Buck DJacoby A, Jacoby A, Baker GA, Chadwick DW. Factors influencing compliance with antiepileptic drug regimes. Seizure. 1997;6(2): $87-93$.

19. Scott J, Pope M. Nonadherence with mood stabilizers: prevalence and predictors. J Clin Psychiatry. 2002;63(5):384-390.

20. Greenhouse WJ, Meyer B, Johnson SL. Coping and medication adherence in bipolar disorder. J Affect Disord. 2000;59(3):237-241.

21. Kleindienst N, Greil W. Are illness concepts a powerful predictor of adherence to prophylactic treatment in bipolar disorder? $J$ Clin Psychiatry. 2004;65(7):966-974.

22. Long AF, Godfrey M, Randall T, Brettle A, Grant MJ. HCPRDU evaluation tool for quantitative studies, University of Leeds, Nuffield Institute for Health, Leeds. Available from: http://usir.salford.ac.uk/12969/. Accessed March 20, 2018

23. Durón RM, Medina MT, Nicolás $\mathrm{O}$, et al. Adherence and complementary and alternative medicine use among Honduran people with epilepsy. Epilepsy Behav. 2009;14(4):645-650.

24. Wahner-Roedler DL, Elkin PL, Vincent A, et al. Use of complementary and alternative medical therapies by patients referred to a fibromyalgia treatment program at a tertiary care center. Mayo Clin Proc. 2005;80(1):55-60.

25. Azaizeh H, Saad B, Cooper E, Said O. Traditional Arabic and Islamic medicine, a re-emerging health aid. Evid Based Complement Alternat Med. 2010;7(4):419-424.

26. Liow K, Ablah E, Nguyen JC, et al. Pattern and frequency of use of complementary and alternative medicine among patients with epilepsy in the midwestern United States. Epilepsy Behav. 2007;10(4):576-582.

27. Mcconnell BV, Applegate M, Keniston A, Kluger B, Maa EH. Use of complementary and alternative medicine in an urban county hospital epilepsy clinic. Epilepsy Behav. 2014;34:73-76.

28. Easterford K, Clough P, Comish S, Lawton L, Duncan S. The use of complementary medicines and alternative practitioners in a cohort of patients with epilepsy. Epilepsy Behav. 2005;6(1):59-62.

29. Peebles CT, Mcauley JW, Roach J, Moore JL, Reeves AL. Alternative medicine use by patients with epilepsy. Epilepsy Behav. 2000; 1(1):74-77.

30. Harms SL, Garrard J, Schwinghammer P, Eberly LE, Chang Y, Leppik IE. Ginkgo biloba use in nursing home elderly with epilepsy or seizure disorder. Epilepsia. 2006;47(2):323-329.

31. Pal SK, Sharma K, Prabhakar S, Pathak A. Psychosocial, demographic, and treatment-seeking strategic behavior, including faith healing practices, among patients with epilepsy in northwest India. Epilepsy Behav. 2008;13(2):323-332.

32. Razali SM, Yassin AM. Complementary treatment of psychotic and epileptic patients in malaysia. Transcult Psychiatry. 2008;45(3): 455-469.

33. Asadi-Pooya AA, Emami M. Perception and use of complementary and alternative medicine among children and adults with epilepsy: the importance of the decision makers. Acta Med Iran. 2014; 52(2):153. 
34. Al Asmi A, Al Maniri A, Al-Farsi YM, et al. Types and sociodemographic correlates of complementary and alternative medicine (CAM) use among people with epilepsy in Oman. Epilepsy Behav. 2013;29(2): 361-366.

35. Tandon M, Prabhakar S, Pandhi P. Pattern of use of complementary/ alternative medicine (CAM) in epileptic patients in a tertiary care hospital in India. Pharmacoepidemiol Drug Saf. 2002;11(6):457-463.

36. Bhalerao MS, Bolshete PM, Swar BD, et al. Use of and satisfaction with complementary and alternative medicine in four chronic diseases: a cross-sectional study from India. 2013;26(2):75-78

37. Naveen GH, Sinha S, Girish N, Taly AB, Varambally S, Gangadhar BN. Yoga and epilepsy: What do patients perceive? Indian J Psychiatry. 2013;55(Suppl 3):S390.

38. Li Q, Chen X, He L, Zhou D. Traditional Chinese medicine for epilepsy. Cochrane Database Syst Rev. 2009;3:CD006454.

39. Kuan YC, Yen DJ, Yiu CH, et al. Treatment-seeking behavior of people with epilepsy in Taiwan: a preliminary study. Epilepsy Behav. 2011;22(2):308-312.

40. Kim IJ, Kang JK, Lee SA. Factors contributing to the use of complementary and alternative medicine by people with epilepsy. Epilepsy Behav. 2006;8(3):620-624.

41. Obeid T, Abulaban A, Al-Ghatani F, Al-Malki AR, Al-Ghamdi A. Possession by 'Jinn' as a cause of epilepsy (Saraa): a study from Saudi Arabia. Seizure. 2012;21(4):245-249.

42. Chapman SC, Horne R, Chater A, Hukins D, Smithson WH. Patients' perspectives on antiepileptic medication: relationships between beliefs about medicines and adherence among patients with epilepsy in UK primary care. Epilepsy Behav. 2014;31:312-320.

43. Ettinger AB, Good MB, Manjunath R, Edward Faught R, Bancroft T. The relationship of depression to antiepileptic drug adherence and quality of life in epilepsy. Epilepsy Behav. 2014;36:138-143.

44. Ferrari CM, de Sousa RM, Castro LH. Factors associated with treatment non-adherence in patients with epilepsy in Brazil. Seizure. 2013; 22(5):384-389.

45. Guo Y, Ding XY, Lu RY, et al. Depression and anxiety are associated with reduced antiepileptic drug adherence in Chinese patients. Epilepsy Behav. 2015;50:91-95.

46. Jones RM, Butler JA, Thomas VA, Peveler RC, Prevett M. Adherence to treatment in patients with epilepsy: associations with seizure control and illness beliefs. Seizure. 2006;15(7):504-508.

47. Shallcross AJ, Becker DA, Singh A, et al. Psychosocial factors associated with medication adherence in ethnically and socioeconomically diverse patients with epilepsy. Epilepsy Behav. 2015;46:242-245.

48. Hovinga CA, Asato MR, Manjunath R, et al. Association of nonadherence to antiepileptic drugs and seizures, quality of life, and productivity: survey of patients with epilepsy and physicians. Epilepsy Behav. 2008;13(2):316-322.

49. Smithson WH, Hukins D, Buelow JM, Allgar V, Dickson J. Adherence to medicines and self-management of epilepsy: a community-based study. Epilepsy Behav. 2013;26(1):109-113.

50. Andrade SE, Kahler KH, Frech F, Chan KA. Methods for evaluation of medication adherence and persistence using automated databases. Pharmacoepidemiol Drug Saf. 2006;15(8):565-574.

51. Nakhutina L, Gonzalez JS, Margolis SA, Spada A, Grant A. Adherence to antiepileptic drugs and beliefs about medication among predominantly ethnic minority patients with epilepsy. Epilepsy Behav. 2011; 22(3):584-586.

52. Bautista RE, Graham C, Mukardamwala S. Health disparities in medication adherence between African-Americans and Caucasians with epilepsy. Epilepsy Behav. 2011;22(3):495-498.
53. Bautista RE, Gonzales W, Jain D. Factors associated with poor seizure control and increased side effects after switching to generic antiepileptic drugs. Epilepsy Res. 2011;95(1-2):158-167.

54. Paschal AM, Rush SE, Sadler T. Factors associated with medication adherence in patients with epilepsy and recommendations for improvement. Epilepsy Behav. 2014;31:346-350.

55. Molugulu N, Gubbiyappa KS, Vasudeva Murthy CR, Lumae L, Mruthyunjaya AT. Evaluation of self-reported medication adherence and its associated factors among epilepsy patients in Hospital Kuala Lumpur. J Basic Clin Pharm. 2016;7(4):105.

56. Zeber JE, Copeland LA, Pugh MJ. Variation in antiepileptic drug adherence among older patients with new-onset epilepsy. Ann Pharmacother. 2010;44(12):1896-1904.

57. Sweileh WM, Ihbesheh MS, Jarar IS, et al. Self-reported medication adherence and treatment satisfaction in patients with epilepsy. Epilepsy Behav. 2011;21(3):301-305.

58. Chesaniuk M, Choi H, Wicks P, Stadler G. Perceived stigma and adherence in epilepsy: evidence for a link and mediating processes. Epilepsy Behav. 2014;41:227-231.

59. Tiv M, Viel JF, Mauny F, et al. Medication adherence in type 2 diabetes: the ENTRED study 2007, a French Population-Based Study. PLoS One. 2012;7(3):e32412.

60. Schachter SC. Botanicals and herbs: a traditional approach to treating epilepsy. Neurotherapeutics. 2009;6(2):415-420.

61. Danesi MA, Adetunji JB. Use of alternative medicine by patients with epilepsy: a survey of 265 epileptic patients in a developing country. Epilepsia. 1994;35(2):344-351.

62. Murthy JM. Some problems and pitfalls in developing countries. Epilepsia. 2003;44 Suppl 1(s1):38-42.

63. Radhakrishnan K, Pandian JD, Santhoshkumar T, et al. Prevalence, knowledge, attitude, and practice of epilepsy in Kerala, South India. Epilepsia. 2000;41(8):1027-1035.

64. Islahudin F, Tan S. Medication knowledge and adherence in nephrology patients. Int J Pharm Bio Sci. 2013;3(1):459-466.

65. Omar MS, San KL. Diabetes knowledge and medication adherence among geriatric patient with type 2 diabetes mellitus. Int J Pharm Pharm Sci. 2014;6(3):103-106.

66. Vervloet M, Linn AJ, van Weert JC, de Bakker DH, Bouvy ML, van Dijk L. The effectiveness of interventions using electronic reminders to improve adherence to chronic medication: a systematic review of the literature. J Am Med Inform Assoc. 2012;19(5):696-704.

67. Grenard JL, Munjas BA, Adams JL, et al. Depression and medication adherence in the treatment of chronic diseases in the United States: a meta-analysis. J Gen Intern Med. 2011;26(10):1175-1182.

68. Koenig HG, George LK, Titus P, Religion TP. Religion, spirituality, and health in medically ill hospitalized older patients. J Am Geriatr Soc. 2004;52(4):554-562.

69. Hatah E, Lim KP, Ali AM, Mohamed Shah N, Islahudin F. The influence of cultural and religious orientations on social support and its potential impact on medication adherence. Patient Prefer Adherence. 2015;9:589.

70. Staniszewska A, Smoleńska E, Religioni U. Health Behaviors Related to the Use of Drugs among Patients with Epilepsy. Am J Health Behav. 2017;41(4):511-517.

71. Szabo CA. Complementary/alternative medicine for epilepsy. Neurology. 2003;61(4):E7-E8. 
Patient Preference and Adherence

Dovepress

\section{Publish your work in this journal}

Patient Preference and Adherence is an international, peer-reviewed, open access journal that focuses on the growing importance of patient preference and adherence throughout the therapeutic continuum. Patient satisfaction, acceptability, quality of life, compliance, persistence and their role in developing new therapeutic modalities and compounds to optimize

Submit your manuscript here: http://www.dovepress.com/patient-preference-and-adherence-journ clinical outcomes for existing disease states are major areas of interest for the journal. This journal has been accepted for indexing on PubMed Central The manuscript management system is completely online and includes a very quick and fair peer-review system, which is all easy to use. Visit http://www. dovepress.com/testimonials.php to read real quotes from published authors. 